\title{
Comparison of egg quality, yolk cholesterol and fatty acid contents of chicken, quail, partridge and pheasant eggs
}

\author{
Ali AYGÜN 1 , Osman OLGUN iD 1 \\ 1Selçuk Üniversitesi, Ziraat Fakültesi, Zootekni Bölümü, Konya
}

Alınıș tarihi: 12 Temmuz 2019, Kabul tarihi: 2 Ekim 2019

Sorumlu yazar: Ali AYGÜN, e-posta: aaygun@selcuk.edu.tr

\begin{abstract}
This experiment was conducted to compare the cholesterol concentrations of yolk and some internal and external quality chicken, quail, partridge and pheasant eggs. Chickens, quails and partridges are housed in cages and pheasants are housed floor pens. Egg quality traits were determined for 20 eggs per poultry species. Egg weight, egg shape index, eggshell strength, albumen ratio, yolk ratio, yolk index, albumen $\mathrm{pH}$, yolk $\mathrm{pH}$, shell ratio, albumen and yolk color characteristics were examined as egg quality analyzes. Ten eggs from each species were used to determine total cholesterol and triglyceride levels of yolks. The highest egg shape index and eggshell strength values were obtained in the pheasant and chicken eggs. The lowest yolk ratio value was obtained in hen eggs. The shell ratio and yolk index of partridge eggs were higher than the other species. Chicken egg had a lower proportion of cholesterol compared with other species. Partridge eggs have a lighter yolk color than other species. There was no statistically significant difference between the other species in terms of egg yolk cholesterol content, while the lowest egg yolk cholesterol value was detected in chicken eggs.
\end{abstract}

Key words: Chicken, quail, partridge, pheasant, cholesterol, egg quality

Tavuk, sülün, keklik ve bıldırcın yumurtalarının kalitesi, kolesterol ve yağ asidi içeriklerinin karşılaştırılması

\section{Öz}

$\mathrm{Bu}$ çalışma, tavuk, sülün, keklik ve bıldırcın yumurtalarının kolesterol seviyelerini ve kalite özelliklerinin karşılaştırılması amaçlanmıştır. Tavuklar, bıldırcınlar ve keklikler kafeste, sülünler ise yer sisteminde barındırılmıştır. Her tür için 20 adet yumurtada yumurta kalite özellikleri belirlenmiştir. Yumurta kalitesi analizleri olarak yumurta ağırlığı, yumurta şekil indeksi, yumurta kabuğu mukavemeti, ak oranı, yumurta sarısı oranı, yumurta sarısı indeksi, ak pH, sarı pH, kabuk oranı, ak ve yumurta sarısı renk özellikleri incelenmiştir. Her bir tür için 10 adet yumurtada toplam kolesterol ve trigliserit seviyeleri belirlenmiştir. Tavuk yumurtaları diğer türlerin yumurtalarına göre daha oval bir yapıdadır. Kırılma direnci bakımından en düşük kırılma direnci bıldırcın yumurtalarında tespit edilmiş olup, tavuk ve sülün yumurtaları arasında kırılma direnci bakımından istatistiki olarak farklılık görülmemiştir. En düşük yumurta sarısı oranı tavuk yumurtalarında tespit edilirken, en yüksek yumurta sarısı sülün ve kekliklerde tespit edilmiştir. Yumurta sarı indeksi en düşük tavuk yumurtasında tespit edilmesine rağmen, en yüksek yumurta sarı indeksi keklik yumurtalarında belirlenmiştir. Yumurta sarı rengi en açık keklik yumurtalarında görülürken, diğer türler arasında sarı renginin yoğunluğu bakımından istatistiki olarak bir farklılık görülmemiştir. En düşük yumurta sarı kolesterol değeri tavuk yumurtasında tespit edilirken diğer türler arasında kolesterol miktarı bakımından istatistiki olarak bir farklılık görülmemiştir.

Anahtar kelimeler: Tavuk, sülün, keklik, bıldırcın, kolesterol, yumurta kalitesi

\section{Introduction}

Eggs are produced not only for chick production but also as an important source of nutrients for humans. 
Eggs contain important nutrients such as protein, essential fatty acids, vitamins and minerals that are necessary for human nutrition. Humans generally consume table eggs, but in small quantities, they consume fertile eggs from other poultry species. In recent years consumer interest has increased for quail, pheasant and partridge eggs (Balcioğlu et al., 2009; Garip et al., 2010; Karabag et al., 2010; Burden, 2013; Kokoszyński, 2017). The structure of the egg is similar in various poultry species, but there are differences in the proportions of these parts (Nys and Guyot, 2011). A few studies have been conducted to compare the cholesterol content and quality of eggs of different poultry species (Song et al., 2000; Choi et al., 2001; Sun et al., 2019). Egg quality is influenced by many factors such as genotype (Basmacioğlu and Ergül, 2005; Şekeroğlu and Sarıca, 2005; Bozkurt and Tekerli, 2009), age (Silversides et al., 2006; Minelli et al., 2007; Akyurek and Okur, 2009), production systems (Van Den Brand et al., 2004; Wang et al., 2009), feed ((Leeson and Caston, 1997; Wu et al., 2005). Basmacioğlu and Ergül (2005) stated that amount of cholesterol in eggs produced in cages were higher than those produced in floor pen. The aim of this study was to compare the eggs of chicken, pheasant, partridge and quail in terms of cholesterol and egg quality. Thus, the physical and nutritional characteristics of quail, pheasant and partridge eggs, which are more interesting in our country in recent years, will be determined.

\section{Material and Method}

The eggs of chicken, pheasant, chukar partridge, and quail were obtained from Selçuk University Agriculture farm in Konya, Turkey. Chickens, quails and partridges are housed in cages and pheasants are housed floor pens. Chicken were fed a ration containing $17 \% \mathrm{HP}$ and $2800 \mathrm{kcal} \mathrm{ME} / \mathrm{kg}$, chukar partridge $17 \%$ and $2900 \mathrm{kcal} \mathrm{ME} / \mathrm{kg}$, pheasant $17 \%$ $\mathrm{HP}$ and $2900 \mathrm{kcal} \mathrm{ME} / \mathrm{kg} \mathrm{kcal}$, and quail 20\% HP and $2900 \mathrm{kcal} \mathrm{ME} / \mathrm{kg}$. Feed and water were provided $a d$ libitum. The eggs were collected daily and stored in the laboratory for one day in the room condition (24 $\pm 2{ }^{\circ} \mathrm{C}$ ) in order to reduce the variation between the first and last ovulated eggs. Egg quality traits were determined for 20 eggs per poultry species. Egg weight was measured using a balance accurate to 0.01 g. Egg shape index (width/length*100) was measured with a micrometer caliper accurate to 0.01 $\mathrm{mm}$. Eggshell strength (kgf) was measured with an Egg Force Reader (06-UM-001, Ver-sion B, Orka
Food Tech. Ltd., Hong Kong, China). After the eggs broken, the albumen and yolk separated using a conventional yolk separator and yolk and albumen were weighed. Albumen and yolk were expressed as percentages relative to total egg weight. Yolk index (height/width) was measured with a measured with a micrometer caliper and a digimatic height gauge accurate to $0.01 \mathrm{~mm}$ (Funk, 1948). Then the $\mathrm{pH}$ of yolk and albumen was measured using $\mathrm{pH}$ meter. Color measurement was performed using a Minolta Chroma Meter CR-400 (Minolta, Osaka, Japan). The lightness $\left(L^{*}\right)$, redness $\left(a^{*}\right)$, and blueness $\left(b^{*}\right)$ color measurements were determined according to the CIELab color space system. The eggshells were washed with water to remove residual albumen and were dried at room condition for 3 days. Then eggshell weight was weighed and expressed as percentages relative to total egg weight.

Ten eggs from each species were used to determine total cholesterol and triglyceride levels of yolks. The contents of total cholesterol and triglyceride of yolks were determined by using the methods of Berrio and Hebert (1990) and Hammad et al. (1996), with modification by GmbH (1989). The eggs were hardboild for $15 \mathrm{~min}$, then the yolks were separated and $0.1 \mathrm{~g}$ samples of yolks were weighed accurately. Yolk lipids were extracted with isopropanol $(4 \mathrm{ml} / 0.1$ of yolk), then vortex-mixed and centrifuged at 3000 rpm for $5 \mathrm{~min}$. The yolk lipids determined in the samples filtered by spectrophotometer using a commercial kit (HUMAN Cholesterol liquicolor for cholesterol, HUMAN Triglucerides liquicolormono for triglyceride).

\section{Statistical methods}

Data were analyzed via one-way ANOVA, and means were compared by Duncan's multiple range test. All analyses were carried out using Minitab Version 16 (Minitab Inc., State College, PA, USA).

\section{Results and Discussion}

The internal and external characteristics of the eggs of some different bird species are shown in Table 1. Differences between species were significant in terms of all internal and external egg quality parameters examined $(\mathrm{P}<0.01)$. The egg weight from the examined species of bird differed significantly $(\mathrm{P}<0.01)$, and increased in the following order: chicken (62.24 g), pheasant (31.47 g), partridge (20.75 g), and quail (13.18 g). Chicken had the highest egg weight, followed by pheasant, partridge, and quail. The higher the live weight in poultry, the higher the egg weight. There is a positive 
relationship between egg weight and body weight (Rahn et al., 1975; Lacin et al., 2008). Egg weight ranges from 60.05 to $67.41 \mathrm{~g}$ in chickens (Curtis et al., 1986; Lacin et al., 2008; Svobodova et al., 2014), 20.55 to $22.44 \mathrm{~g}$ in partridge (Garip et al., 2010;
Caglayan et al., 2014), 10.40 to $13.70 \mathrm{~g}$ in quails (Camci et al., 2002; Kumari et al., 2008; Alkan et al., 2010 ) and 31.00 to $31.80 \mathrm{~g}$ in pheasants (Kirikçi et al., 2005; Garip et al., 2010).

Table 1. The internal and external quality of eggs of different poultry species

\begin{tabular}{|c|c|c|c|c|c|c|}
\hline Traits & Chicken & Pheasant & Partridge & Quail & SEM & P values \\
\hline Egg weight, g & $62.24^{\mathrm{a}}$ & $31.47^{b}$ & $20.75^{c}$ & $13.18^{\mathrm{d}}$ & 0.312 & 0.001 \\
\hline Egg shape index, \% & $77.22^{b}$ & $81.96^{a}$ & $75.97 b$ & $76.89 b$ & 0.536 & 0.001 \\
\hline Eggshell strength (kgf) & $3.81^{\mathrm{a}}$ & $3.94^{\mathrm{a}}$ & $3.12^{\mathrm{b}}$ & $1.62^{\mathrm{c}}$ & 0.098 & 0.001 \\
\hline Albumen ratio, $\%$ & $64.70^{\mathrm{a}}$ & $56.93^{c}$ & $55.67 \mathrm{c}$ & $59.85^{b}$ & 0.444 & 0.001 \\
\hline Yolk ratio, $\%$ & $25.21^{c}$ & $32.63^{a}$ & $32.88^{a}$ & $30.59 \mathrm{~b}$ & 0.395 & 0.001 \\
\hline Yolk index & 0.39 c & $0.45^{b}$ & $0.49 \mathrm{a}$ & $0.45^{b}$ & 0.006 & 0.001 \\
\hline Albumen pH & $8.29 \mathrm{~b}$ & $8.41^{\mathrm{b}}$ & $8.57 a$ & $8.68^{a}$ & 0.03 & 0.001 \\
\hline Yolk pH & $5.71^{c}$ & $5.95^{\mathrm{a}}$ & $5.95^{\mathrm{a}}$ & $5.85^{b}$ & 0.04 & 0.001 \\
\hline Shell ratio, $\%$ & $10.00^{b c}$ & $10.44^{b}$ & $11.45^{\mathrm{a}}$ & $9.56^{c}$ & 0.157 & 0.001 \\
\hline
\end{tabular}

a-d Values bearing different superscript in rows are statistically different; $\mathrm{P}<0.01$.

A greater shape index $(\mathrm{P}<0.01)$ was noticeable in the pheasant egg compared to the other species eggs. This means that the pheasant eggs are more rounded that the eggs of other species. The shape index mostly detected are sharp pointed, normal (standard), and round eggs which are enumerated on the SI as $<72,72-76$, and $>76$, respectively (Altuntaş and Şekeroğlu, 2008). According to the shape indexes obtained from our study, only partridge eggs show normal shape index value (75.97\%). The eggs of other species appear to have a more rounded shape. The more rounded and sharp pointed eggs are of low commercial value and the problem is that they are placed in viols. Furthermore, the probability of breakage during transportation is higher than for normal shaped eggs (Jacob et al., 2000).

Chicken and pheasant had the highest eggshell breaking strength, followed partridge and quail eggs. Eggshell breakage is important for poultry industry during egg collection, transport, packaging and storage processes. The variety and density of eggshell proteins and layers regulate the breaking strength of the egg (Hincke et al., 2008; Fathi et al., 2010). The different species of eggshell strength may be due to the fact that the amount of shell matrix proteins and layers is different.

Although the albumin ratio of partridge and pheasant eggs was lower than that of the other two species, yolk or shell ratios were found to be higher than these species.. The lowest and highest yolk indexes were detected in chicken and partridge eggs, respectively. Albumen $\mathrm{pH}$ was significantly higher
$(\mathrm{P}<0.01)$ in quail and partridge eggs, and lower in the chicken and pheasant eggs, while yolk $\mathrm{pH}$ was significantly higher $(\mathrm{P}<0.01)$ in partridge and pheasant eggs, and lower in the chickens. Similar results was obtained by Vlčková et al. (2019) who stated that chicken eggs yolk ratio (\%) was lower than quails eggs yolk ratio (\%). Egg quality was affected by strains, age, nutrition and environment (Hocking et al., 2003; Roberts, 2004; Aygun and Yetișir, 2014; Sekeroglu et al., 2014). Partridge, quail and pheasants, unlike chickens, are mainly used for hatching eggs. Ar and Yom-Tov (1978) reported that precocial birds produce eggs with significantly more yolk than altricial ones to supply more nutrients for chicks to survive independently.

The albumen and yolks colors of different avian specious eggs are shown Table 2 . The difference between $a^{*}$ and $b^{*}$ albumen of the different species is insignificant $(P>0.05)$. The albumen $L^{*}$ value of chicken and pheasant eggs was higher than the other species $(\mathrm{P}<0.01)$. The yolk $\mathrm{L}^{*}$ and $\mathrm{b}^{*}$ values of quail egg were significantly higher than chicken and pheasant $(\mathrm{P}<0.01)$. The yolk $\mathrm{a}^{*}$ value of the partridge egg was markedly lower than other species $(\mathrm{P}<0.01)$. Egg yolk color is considered by consumers as an important quality criterion. Egg yolk color changes depending on the ration of the birds. The more carotenoids in the ration, the darker the egg yolk color (Schwägele, 2011).

The egg yolk cholesterol, triglyceride and fatty acids levels of the different species are shown in Table 3 . Egg yolk triglyceride levels of different species were found to be similar $(\mathrm{P}>0.05)$. 
Table 2. Color values of albumen and yolk of chicken, pheasant, partridge and quail egg

\begin{tabular}{lcccccc}
\hline Parameters & Chicken & Pheasant & Partridge & Quail & SEM & P values \\
\hline Albumen & & & & & \\
\hline L $^{*}$ & $36.006^{\mathrm{b}}$ & $39.388^{\mathrm{b}}$ & $49.500^{\mathrm{a}}$ & $58.857^{\mathrm{a}}$ & 2.413 & 0.001 \\
$\mathrm{a}^{*}$ & -1.105 & -2.232 & -2.686 & -2.349 & 0.472 & 0.193 \\
$\mathrm{~b}^{*}$ & 11.502 & 14.752 & 16.023 & 12.342 & 5.917 & 0.169 \\
\hline Yolk & & & & & 0.536 & 0.001 \\
\hline $\mathrm{L}^{*}$ & $52.849^{\mathrm{b}}$ & $52.456^{\mathrm{b}}$ & $54.379^{\mathrm{ab}}$ & $55.892^{\mathrm{a}}$ & 0.395 & 0.001 \\
$\mathrm{a}^{*}$ & $5.159^{\mathrm{a}}$ & $4.289^{\mathrm{a}}$ & $2.388^{\mathrm{b}}$ & $4.307^{\mathrm{a}}$ & 0.004 \\
$\mathrm{~b}^{*}$ & $42.610^{\mathrm{b}}$ & $42.509^{\mathrm{b}}$ & $46.167^{\mathrm{ab}}$ & $53.700^{\mathrm{a}}$ & 2.113 & 0.004 \\
\hline
\end{tabular}

ab Values bearing different superscript in rows are statistically different; $\mathrm{P}<0.01$.

Table 3. Triglyceride and cholesterol contents of chicken, pheasant, partridge and quail egg yolks

\begin{tabular}{|c|c|c|c|c|c|c|}
\hline Parameters & Chicken & Pheasant & Partridge & Quail & SEM & $P$ values \\
\hline Triglyceride, mg/dl & 173.24 & 172.46 & 177.42 & 175.36 & 1.51 & 0.112 \\
\hline Cholesterol mg/dl & $136.87 b$ & $159.72^{\mathrm{a}}$ & $166.16^{\mathrm{a}}$ & $154.12^{\mathrm{a}}$ & 2.89 & 0.001 \\
\hline
\end{tabular}

ab Values bearing different superscript in rows are statistically different; $\mathrm{P}<0.01$.

The level of yolk cholesterol in chicken egg was found to be significantly lower than in quail, partridge or pheasant eggs $(\mathrm{P}<0.01)$. But no significant differences were found for cholesterol among quail, partridge and pheasant. These results may be related to the result of more intensive selection in chickens compared to other birds. On the other hand, it may also be due to the nutrient content in the feed of these animals, genotype, production systems and age (Chand, 1987; Oloyo, 2003; Basmacioğlu and Ergül, 2005; Zemkova et al., 2007; Canogullari et al., 2009; Anderson, 2011). Cholesterol concentration in egg may be influenced by diet content (Li-Chan and Kim, 2008). Many studies have shown that nutrient cholesterol does not significantly affect on cholesterolaemia (Kritchevsky, 2000; Kritchevsky and Kritchevsky, 2000; Herron and Fernandez, 2004). It was stated that consumption of one or two eggs per day did not increase cholesterolaemia or the risk of cardiovascular disease (Dawber et al., 1982; Hu et al., 1999).

\section{Conclusion}

The results indicated that egg quality and cholesterol content varied within poultry species. Because of the higher cholesterol levels of pheasant, partridge and quail eggs, it is useful to pay attention to the consumption of these eggs as an alternative to chicken eggs.

\section{References}

Akyurek, H., Okur, A.A., 2009. Effect of storage time, temperature and hen age on egg quality in freerange layer hens. Journal of Animal and Veterinary Advances, 8: 1953-1958.

Alkan, S., Karabag, K., Galic, A., Karsli, T., Balcioglu, M.S., 2010. Effects of selection for body weight and egg production on egg quality traits in Japanese quails (Coturnix coturnix japonica) of different lines and relationships between these traits. Kafkas Universitesi Veteriner Fakultesi Dergisi, 16: 239244.

Altuntaş, E., Şekeroğlu, A., 2008. Effect of egg shape index on mechanical properties of chicken eggs. Journal of Food Engineering, 85: 606-612.

Anderson, K.E., 2011. Comparison of fatty acid, cholesterol, and vitamin $\mathrm{A}$ and $\mathrm{E}$ composition in eggs from hens housed in conventional cage and range production facilities. Poultry Science, 90: 1600-1608.

Ar, A., Yom-Tov, Y., 1978. The evolution of parental care in birds. Evolution, 32: 655-669.

Aygun, A., Yetişir, R., 2014. Effects of hen age and force molting programs on some egg quality traits in laying hens. Selcuk Journal of Agriculture and Food Sciences, 28: 58-62.

Balcioğlu, M.S., Kizilkaya, K., Karabağ, K., Alkan, S., Yolcu, H.İ., Şahin, E., 2009. Comparison of growth characteristics of chukar partridges (Alectoris chukar) raised in captivity. Journal of Applied Animal Research, 35: 21-24. 
Basmacioğlu, H., Ergül, M., 2005. Research on the factors affecting cholesterol content and some other characteristics of eggs in laying hens the effects of genotype and rearing system. Turkish Journal of Veterinary and Animal Sciences, 29: 157-164.

Berrio, L., Hebert, J., 1990. The effect of adding cholesterol to laying hen diets as powder or predissolved in fat. Poultry Science, 69: 972-976.

Bozkurt, Z., Tekerli, M., 2009. The effects of hen age, genotype, period and temperature of storage on egg quality. Kafkas Üniversitesi Veteriner Fakültesi Dergisi, 15: 517-524.

Burden, D., 2013. Game-Bird Preserve Business Development Guide.

Caglayan, T., Kirikci, K., Aygun, A., 2014. Comparison of hatchability and some egg quality characteristics in spotted and unspotted partridge (Alectoris chukar) eggs. Journal of Applied Poultry Research, 23: 244251.

Camci, Ö., Erensayin, C., Aktan, S., 2002. Relations between age at sexual maturity and some production characteristics in quails. Archiv für Geflügelkunde, 66: $280-282$.

Canogullari, S., Karaman, M., Erdogan, Z., Baylan, M., Kucukgul, A., Duzguner, V., Ozugur, A.K., 2009. Effect of garlic powder on egg yolk and serum cholesterol and performance of laying hens. Bulletin of the Veterinary Institute in Pulawy, 53: 515-519.

Chand, D., 1987. Comparison of egg-yolk cholesterol levels in white plymouth rock, white cornish and newhampshire breeds of poultry. Indian Veterinary Journal, 64: 1024-1028.

Choi, S., Song, K., Oh, H., 2001. Cholesterol contents and fatty acid composition of chukar, pheasant, guinea fowl and quail egg yolk. Asian-Australasian Journal of Animal Sciences, 14: 831-836.

Curtis, P., Gardner, F., Mellor, D., 1986. A comparison of selected quality and compositional characteristics of brown and white shell eggs. III. Composition and nutritional characteristics. Poultry Science, 65: 501-507.

Dawber, T.R., Nickerson, R.J., Brand, F.N., Pool, J., 1982. Eggs, serum cholesterol, and coronary heart disease. The American Journal of Clinical Nutrition, 36: 617-625.

Fathi, M., Afifi, Y.K., El-Safty, S., 2010. Utlrastructural diversity of eggshell quality in some Egyptian local breeds of chicken. Egyptian Poultry Science Journal, 30: 813-827.
Funk, E., 1948. The relation of the yolk index determined in natural position to the yolk index as determined after separating the yolk from the albumen. Poultry Science, 27: 367-367.

Garip, M., Caglayan, T., Kirikci, K., Gunlu, A., 2010. A comparison of egg quality characteristics of partridge and pheasant eggs, P. colchicus, A. graeca. Journal of Animal and Veterinary Advances, 9: 299301.

GmbH, B.M., 1989. Methods of biochemical analysis and food analysis: Using test-combinations. Boehringer Mannheim GmbH.

Hammad, S., Siegel, H., Marks, H., 1996. Dietary cholesterol effects on plasma and yolk cholesterol fractions in selected lines of Japanese quail. Poultry Science, 75: 933-942.

Herron, K.L., Fernandez, M.L., 2004. Are the current dietary guidelines regarding egg consumption appropriate? The Journal of Nutrition, 134: 187190.

Hincke, M.T., Wellman-Labadie, O., McKee, M.D., Gautron, J., Nys, Y., Mann, K., 2008. Biosynthesis and structural assembly of eggshell components, In: Mine, Y. (Ed.), Egg Bioscience and Biotechnology, John Wiley \& Sons, New Jersey, pp. 97-128.

Hocking, P., Bain, M., Channing, C., Fleming, R., Wilson, S., 2003. Genetic variation for egg production, egg quality and bone strength in selected and traditional breeds of laying fowl. British Poultry Science, 44: 365-373.

Hu, F.B., Stampfer, M.J., Manson, J.E., Rimm, E.B., Wolk, A., Colditz, G.A., Hennekens, C.H., Willett, W.C., 1999. Dietary intake of $\alpha$-linolenic acid and risk of fatal ischemic heart disease among women. The American Journal of Clinical Nutrition, 69: 890-897.

Jacob, J.P., Miles, R.D., Mather, F.B., 2000. Egg quality. Cooperative Extension Service, Institute of Food and Agricultural Sciences (IFAS), University of Florida PS 24.

Karabag, K., Alkan, S., Mendes, M., 2010. Classification tree method for determining factors that affecting hatchability in Chukar partridge (Alectoris chukar) eggs. Kafkas Üniversitesi Veteriner Fakültesi Dergisi, 16: 723-727.

Kirikçi, K., Günlü, A., Garip, M., 2005. Some quality characteristics of pheasant (Phasianus colchicus) eggs with different shell colors. Turkish Journal of Veterinary and Animal Sciences, 29: 315-318.

Kokoszyński, D., 2017. Guinea Fowl, Goose, Turkey, Ostrich, and Emu Eggs, In: Patricia Y, H. (Ed.), Egg innovations and strategies for improvements, 
Academic Press, Elsevier, Oxford, United Kingdom, pp. 33-43.

Kritchevsky, D., 2000. Dietary fat and disease; what do we know and where do we stand. Egg Nutrition and Biotechnology, 3-13.

Kritchevsky, S.B., Kritchevsky, D., 2000. Egg consumption and coronary heart disease: an epidemiologic overview. Journal of the American College of Nutrition, 19: 549S-555S.

Kumari, B.P., Gupta, B.R., Prakash, M.G., Reddy, A.R., 2008. A study on egg quality traits in Japanese quails (Coturnix coturnix japonica). Tamilnadu Journal Veterinary and Animal Sciences, 4: 227-231.

Lacin, E., Yildiz, A., Esenbuga, N., Macit, M.J., 2008. Effects of differences in the initial body weight of groups on laying performance and egg quality parameters of Lohmann laying hens. Czech Journal of Animal Science, 53: 466-471.

Leeson, S., Caston, L., 1997. A problem with characteristics of the thin albumen in laying hens. Poultry Science, 76: 1332-1336.

Li-Chan, E.C., Kim, H.O., 2008. Structure and chemical composition of eggs, In: Mine, Y. (Ed.), Egg bioscience and biotechnology, John Wiley and Sons Inc., New Jersey, New Jersey, pp. 1-96.

Minelli, G., Sirri, F., Folegatti, E., Meluzzi, A., Franchini, A., 2007. Egg quality traits of laying hens reared in organic and conventional systems. Italian Journal of Animal Science, 6: 728-730.

Nys, Y., Guyot, N., 2011. Egg Formation and Chemistry, In: Nys, Y., Bain, M., Immerseel, F.I. (Eds.), Improving the Safety and Quality of Eggs and Egg Products, Woodhead Publishing, Elsevier, Cambridge, pp. 83132.

Oloyo, R., 2003. Effect of age on total lipid and cholesterol of hen eggs. Indian Jounal of Animal Science, 73: 94-96.

Rahn, H., Paganelli, C.V., Ar, A., 1975. Relation of avian egg weight to body weight. The Auk, 92: 750-765.

Roberts, J.R., 2004. Factors affecting egg internal quality and egg shell quality in laying hens. The Journal of Poultry Science, 41: 161-177.

Schwägele, F., 2011. Egg quality assurance schemes and egg traceability, In: Nys, Y., Bain, M., Immerseel, F.I. (Eds.), Improving the Safety and Quality of Eggs and Egg Products, Woodhead Publishing, Elsevier, pp. 62-80.
Sekeroglu, A., Duman, M., Tahtali, Y., Yildirim, A., Eleroglu, H., 2014. Effect of cage tier and age on performance, egg quality and stress parameters of laying hens. South African Journal of Animal Science, 44: 288-297.

Silversides, F., Korver, D., Budgell, K., 2006. Effect of strain of layer and age at photostimulation on egg production, egg quality, and bone strength. Poultry Science, 85: 1136-1144.

Song, K., Choi, S., Oh, H., 2000. A comparison of egg quality of pheasant, chukar, quail and guinea fowl. Asian Australasian Journal of Animal Sciences, 13: 986990.

Sun, C., Liu, J., Yang, N., Xu, G., 2019. Egg quality and egg albumen property of domestic chicken, duck, goose, turkey, quail, and pigeon. Poultry Science, 98: 4516-4521.

Svobodova, J., Tůmová, E., Englmaierová, M., 2014. The effect of housing system on egg quality of Lohmann white and Czech hen. Acta Fytotechnica et Zootechnica, 17: 44-46.

Şekeroğlu, A., Sarıca, M., 2005. Serbest yetiştirme (freerange) sisteminin beyaz ve kahverengi yumurtacl genotiplerin yumurta verim ve kalitesine etkisi. Tavukçuluk Araştırma Dergisi, 6: 10-16.

Van Den Brand, H., Parmentier, H., Kemp, B., 2004. Effects of housing system (outdoor vs cages) and age of laying hens on egg characteristics. British Poultry Science, 45: 745-752.

Vlčková, J., Tůmová, E., Míková, K., Englmaierová, M., Okrouhlá, M., Chodová, D., 2019. Changes in the quality of eggs during storage depending on the housing system and the age of hens. Poultry Science, 98: 6187-6193.

Wang, K., Shi, S., Dou, T., Sun, H., 2009. Effect of a freerange raising system on growth performance, carcass yield, and meat quality of slow-growing chicken. Poultry Science, 88: 2219-2223.

Wu, G., Bryant, M., Voitle, R., Roland Sr, D., 2005. Effect of dietary energy on performance and egg composition of Bovans White and Dekalb White hens during phase I. Poultry Science, 84: 16101615.

Zemkova, L., Simeonovova, J., Lichovnikova, M., Somerlikova, K., 2007. The effects of housing systems and age of hens on the weight and cholesterol concentration of the egg. Czech Journal of Animal Science, 52: 110-115. 